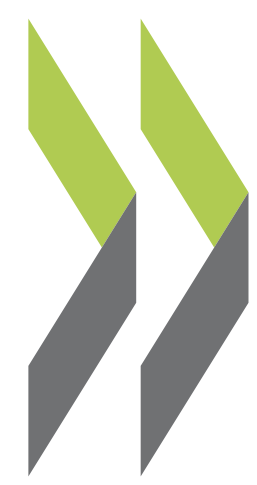

OECD Local Economic and Employment Development (LEED) Papers 2012/10

\title{
Accountability in Decentralised Employment Service Regimes
}

\section{Hugh Mosley}




\section{Accountability in Decentralised}

\section{Employment Service Regimes}

HUGH G. MOSLEY

May 2012 
Accountability in Decentralised

Employment Service Regimes 


\section{ACKNOWLEDGEMENTS}

The author is indebted to Francesca Froy, OECD LEED, and Donna Wood, University of Victoria, for extensive and helpful comments on the entire text and to Kristel Bogaerts, Herman Deleeck Centre for Social Policy, University of Antwerp, and Thomas Bredgaard and Flemming Larsen, Centre for Labour Market Research, Aalborg University, for comments on Belgium and Denmark respectively. The author alone is responsible for the contents. Contact hugh.mosley@arcor.de

Dr. Hugh Mosley is a Berlin-based labour market researcher and consultant. He was a Senior Research Fellow at the Social Science Research Centre (WZB) in Berlin from 1986 to 2009, where he directed numerous comparative studies and programme evaluations. His recent work has continued to focus on active labour market policies and implementation issues, especially public employment service reforms. He has worked frequently as a consultant to the European Commission and the OECD on labour market policy. 


\section{Table of contents}

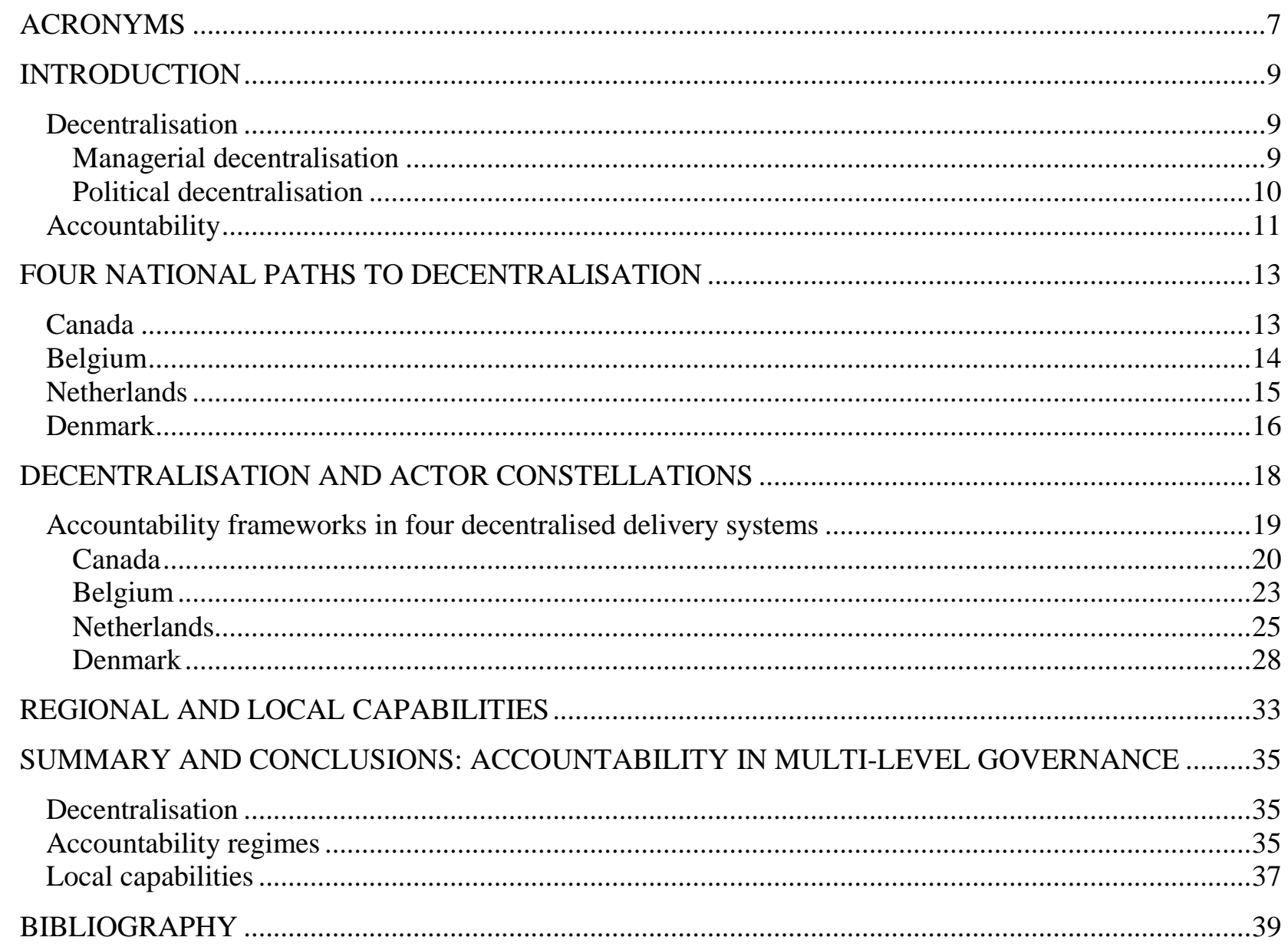




\section{ACRONYMS}

AEI

AMS

GTB

HRSDC

LEED

LMA

LMADP

LMDA

MBO

NEO

OCMW

PES

PETL

PWA

RMI

SZW

TIOW

UWV

VDAB

VVSG

WWB
Alberta Employment and Immigration, Canada

National Labour Market Authority (Arbejdsmarkedsstyrelsen), Denmark

Specialised Labour Counselling Services (Gespecialiseerde Trajectbepalings-

en Begeleidingsdienst), Belgium

Human Resources and Skills Development Canada

Local Employment and Economic Development Programme, OECD

Labour Market Agreements, Canada

Labour Market Agreement for Disabled Persons, Canada

Labour Market Development Agreements, Canada

Management by objectives

National Employment Office, Belgium

Public Social Assistance Centre (Openbaar Centrum voor Maatschappelijk

Welzijn), Belgium

Public Employment Service

Department of Post-secondary Education, Training and Labour, New

Brunswick, Canada

Local Employment Agency (Plaatselijk WerkgelegenheidsAgentschap),

Belgium

Right on Societal Integration (Recht op Maatschappelijke Integratie), Belgium

Ministry of Social Affairs and Employment (Ministerie van Sociale Zaken en

Werkgelegenheid), Netherlands

Targeted Initiative for Older Workers, Canada

Public Employment Service, Netherlands

Public Employment Service (Vlaamse Dienst voor Arbeidsbemiddeling),

Flanders

Flemish Association of Cities and Municipalities (Vlaamse Vereniging van

Steden en Gemeenten), Flanders

Work and Social Assistance Act, Netherlands 


\section{INTRODUCTION}

This synthetic paper compares and contrasts accountability frameworks and issues in four OECD countries with decentralised delivery systems for active labour market policies (Canada, Belgium, the Netherlands and Denmark). It draws on the results of the OECD LEED study "Managing Accountability and Flexibility" conducted in the four countries between 2009 and 2011, and contextualises the findings in the wider academic debate in relation to performance management and accountability. ${ }^{1}$

The paper proceeds as follows: this introduction defines and discusses key concepts of decentralisation and accountability; the first section presents an overview of the background and institutional setting of political decentralisation in the four countries examined; the following section compares the types of decentralisation and the resulting actor constellations; you will then find a section which summarises and discusses the four national accountability frameworks; the next section discusses regional and local capability issues in the different employment systems; the final section summarises the findings and principal conclusions.

\section{Decentralisation}

In the past three decades there has been a strong trend toward decentralisation in active labour market policies in OECD countries (see OECD 1999; Giguère and Froy 2009; Froy 2011). Responsibility for policy or implementation has been increasingly transferred from the central to the regional or local levels. This trend reflects broader developments in public government, especially devolution of central governmental responsibilities to the regions (e.g. Belgium, Italy, Spain), and in public administration ('New Public Management'). Policy makers have also become increasingly aware of the importance of the local dimension of labour market policy and the need to facilitate more tailor-made policies in co-operation with other local actors that have a regional fit. Employment services to reintegrate the unemployed or to meet other local challenges cannot be implemented according to detailed and standardised national rules in the same way as can the payment of income support benefits.

There have been two principal types of decentralisation: (i) managerial decentralisation in which regional and local public employment service (PES) offices are given increased operative flexibility in implementing national policy objectives and (ii) political decentralisation or devolution, which usually entails a more far-reaching delegation of responsibility from the national PES to the sub-national (regional, state, or municipal) levels of government (Mosley 2003, 2009).

\section{Managerial decentralisation}

Managerial or inner-organisational decentralisation usually takes the form of management by objectives (MBO) or performance management. It is the classical managerial strategy for reconciling local flexibility and accountability and the common denominator for diverse inner-organisational

\footnotetext{
${ }^{1}$ The project examines the management of flexibility and accountability in active labour market regimes in four OECD countries: Canada (focusing on Alberta and New Brunswick), Belgium (focusing on Flanders), the Netherlands and Denmark. Country experts prepared national reports based on a common analytical framework and standardised methodology: (1) a detailed OECD e-questionnaire to local employment offices, (2) interviews with government officials and service delivery providers, (3) a series of roundtables in different localities and at the national level with government officials and other policy actors. See the project report for further details: Froy et al., 2011.
} 
decentralisation strategies. ${ }^{2}$ The central PES organisation sets, on the basis of a national contract with the responsible ministry, overall goals and operational targets that are then adapted to local circumstances and can be flexibly implemented at the local level. Operating units are typically given a great deal more discretion in the use of funds and personnel and in the mix and management of programmes than in more traditional administrative structures but are expected to achieve centrally set targets or goals based on which their performance is assessed.

Management by objectives (or management by results) is the central element of diverse public sector reforms in the tradition of 'new public management.' Emphasis is on outputs or outcomes against targets rather than on controlling inputs and adherence to detailed regulations. Managers and operating units at regional and local levels are relatively free in their choice of strategies and programmes to achieve the agreed performance targets. In principle MBO within a national PES organisation represents not an abandonment of central direction of the PES organisation but rather a refinement.

\section{Political decentralisation}

In political decentralisation or devolution lower tiers of government play a central role in policy and implementation. In such complex multilevel governance structures the relationship between central and regional or local authorities is inherently less hierarchical and more negotiated because the implementing agencies are no longer subordinate departments of a central administration but autonomous political entities (Mosley, 2010).

There are a variety of forms of political decentralisation:

1. Federalism in which responsibility for programmes previously managed at the national level is devolved to state or provincial governments that are constitutionally politically and administratively highly independent actors, for example, in the United States or in Canada.

2. Regionalisation is another type of political decentralisation. Several previously highly centralised political-administrative systems have devolved power to strong regional governments, including major responsibilities in the field of labour market and employment policy, for example, in the case of Spain and Italy but also Belgium (Flanders), which is discussed below.

3. Municipalisation of service delivery is a third type of political decentralisation. This is found especially in the organisation of labour market services for social assistance recipients, which in many countries is primarily the responsibility of the local authorities. This type of decentralisation is practiced, for example, for employment services for social assistance recipients in Germany and in the Netherlands. In Denmark it has been adopted as a framework

${ }^{2}$ Ideally, typically it entails the following elements (Mosley, Schütz and Breyer, 2001; Mosley, 2003):

1) The definition of a limited number of organisational goals and corresponding performance indicators;

2) Delegation of these performance targets to subordinate levels of the organisation;

3) Flexibility in the sense of a low density of generally binding bureaucratic rules and procedures. Managers and operating units at regional and local levels are relatively free in their choice of strategies and programmes to achieve the agreed performance targets for their units.

4) Monitoring and controlling of performance against targets.

5) Sanctions for either the operative unit or for individual managers. In contrast to traditional bureaucratic administration, the emphasis is on outputs or outcomes against targets rather than on controlling inputs and adherence to detailed regulations. 
for employment services for all client groups, including the insured unemployed. The Dutch and Danish cases are discussed in some detail below.

Political decentralisation and managerial decentralisation in the form of management by objectives are not mutually exclusive. Performance management is a management approach to reconciling flexibility and accountability in labour market policy that can be found at any level of government.

\section{Accountability}

Government is typically concerned with ensuring four principal types of accountability, even in decentralised delivery systems (Mosley, 2003):

1. Political accountability: Democratic public administration requires political accountability to elected government officials, parliaments and the public;

2. Legal accountability: Public agencies are expected to act on the basis of the rule of law and in conformity with applicable regulations;

3. Fiscal accountability: Correctness and economy in the use of public monies (audits);

4. Performance accountability: Output or outcome oriented effectiveness and efficiency.

\section{Political accountability}

Accountability to elected government officials is the core of political accountability. Labour market policy is in most countries a national responsibility and plays, as a rule, a prominent role in national politics. Responsibility for policy does not preclude a far reaching decentralisation of implementation. Even in countries with relatively decentralised delivery systems, there is usually a strong effort to retain an overall common policy framework and some accountability standards (e.g. USA, Canada, Spain). In multilevel governmental systems, however, political accountability is ambiguous since there are elected leaders at various levels, including regional and local actors, who may assert claims to shape not only implementation but to adapt policy. The perceived need for national political accountability differs across countries, and is ultimately a political decision.

\section{Legal accountability}

Public agencies are expected to act on the basis of the rule of law and guarantee equal rights to citizens. This norm may conflict with decentralisation, which entails increased variety in implementation with more tailor-made policies. ${ }^{3}$ Insofar as decentralisation weakens central legal and policy supervision, it results in different levels of oversight and different interpretations of law and regulations in different locations. Both municipal models (Netherlands and Denmark) discussed below entail an increase in flexibility (and hence variety) in the organisation of service delivery and implementation practice.

\section{Fiscal accountability}

Ensuring correctness and economy in the use of public monies is inherently more problematic in multi-level governance because the divergence of interests between the principal and agent is likely to be greater, the possibilities for control more limited, and the costs of control higher. There may be, moreover, in general less incentive for fiscal accountability on the part of local authorities if local expenditures are

\footnotetext{
3 "Decentralisation leads to greater variety in the provision of public goods, which are tailored to better suit local populations" (Tiebout, 1956).
} 
not tied to local revenue generation "since vertical fiscal transfers may allow local officials to ignore the financial consequences of mismanagement" (Fisman and Gatti, 2002).

\section{Performance accountability}

Performance management in MBO-type systems is based on a principal-agent model in which the central or top level (the principal) defines goals and objectives that are to be implemented by lower-level operating units. Such management systems with their strong emphasis on quantitative targets are particularly prone to agency problems. The information advantage of the agent (operative agency) can be abused in MBO-systems in various ways, especially in reporting results. The monitoring costs of guaranteeing agents' compliance are relatively high.

National traditions differ. In more traditional systems of public administration the accountability framework emphasises legal and fiscal accountability and the separation of administration and politics, whereas 'new public management' emphasises organisational decentralisation, managerial discretion, performance measures, quality standards and service in accountability frameworks. Economic incentives also play a surprisingly important role in the accountability framework of the two municipalised employment service systems discussed below (the Netherlands and Denmark).

Accountability regimes and accountability problems depend in good part on the service delivery model and the extent and type of decentralisation (Mosley and Sol, 2005; Mosley, 2009). Multi-level governance of employment services, which we find in different forms in all the countries examined in this paper, is a special case. In multi-level governance $\mathrm{MBO}$ is usually combined with political decentralisation. In Canada and the USA, for example, performance agreements are negotiated with the individual provinces and states. ${ }^{4}$ In such institutional configurations, however, MBO functions typically only as MBO-light, with correspondingly greater flexibility for the responsible regional or municipal governments. This is the case for structural reasons: the underlying power relationship and information and control problem are fundamentally altered in comparison with MBO in a national PES organisation. The interests of the principal and the agent in the multi-level system are, as a rule, much more diverse, the possibilities of control more limited and more costly. There is, moreover, a greater variety of organisational forms with a correspondingly lower level of standardisation and comparability in labour market and performance data. Moreover, the leverage of central authorities over politically independent state, provincial or municipal governments is limited. In short, the principal-agent relationship inherent in MBO is applicable only in a much weakened form in multi-level governance.

\footnotetext{
${ }^{4}$ For example, in the US performance measures (e.g. employment, retention, earnings and credential attainment) are established by federal statute but the actual levels of performance are set by the state in negotiations with the federal level (Froy and Giguère, 2010).
} 


\section{FOUR NATIONAL PATHS TO DECENTRALISATION}

All four countries examined ${ }^{5}$ represent examples of political decentralisation of responsibility for employment policy in a context of multi-level governance. Nevertheless, performance management and management by objectives still play an important role either as a management strategy for the responsible regional PES organisations in Canada (Alberta and New Brunswick) and in Belgium (Flanders), as well as in individual municipalities, which are responsible for the implementation of active policies in the Netherlands and Denmark. Moreover, there is still a weaker MBO-light in the federal-provincial relationship in Canada. In the Netherlands, and to a lesser extent in Denmark, financial incentives rather than traditional tools of performance management are now central to the accountability framework. This is an interesting and innovative approach toward the special problems of maintaining central accountability under conditions of political decentralisation.

\section{Canada}

Canada has a federal system of government in which the ten individual provinces and three territories have major responsibilities. Provincial governments have always had full responsibility for the uninsured unemployed through provincial social assistance programmes, supported by federal funding contributions. However, in the past the Government of Canada was responsible for unemployment benefits and active employment measures for the insured unemployed. In 1996 the Government of Canada started to devolve responsibility for the design and delivery of nationally funded active employment policies for the insured unemployed to the provinces, while the regulation and administration of unemployment insurance remained a national responsibility.

The Canadian Labour Ministry (HRSDC) implemented this policy by concluding a series of voluntary bilateral agreements with the provinces and territories. The Labour Market Development Agreements (LMDA) were the first and most important of these. The first devolved agreement was concluded with Alberta in 1996, and over time with all other provinces and territories finishing with the Yukon Territory in 2010. Some provinces started with co-managed arrangements before undertaking fully devolved arrangements, while others took on the federal responsibilities as soon as they were offered. The devolved LMDA agreements provide not only for a transfer of funding, but also for the transfer of federal staff and assets to the provincial and territorial governments (Wood, 2010).

Active measures for the uninsured unemployed, if any, were until recently primarily the sole responsibility of the provinces. In 2007 Canada introduced Labour Market Agreements (LMA), a new type of federal-provincial partnership agreement that filled a major gap by making additional federal funding available to the uninsured unemployed (e.g. immigrants, youth, women re-entering the labour market). There are also separate federal-provincial agreements for older workers and disabled persons. ${ }^{6}$ Most of these agreements received funding boosts in response to the recent economic downturn. Despite devolution the federal government has retained responsibility for youth, aboriginal persons and pan-Canadian activities. Today approximately $85 \%$ of federally-funded active measures in Canada are the responsibility of provincial and territorial governments and Aboriginal groups. The only province with municipal involvement is Ontario, Canada's largest province.

\footnotetext{
${ }^{5}$ See the country reports for Canada (Wood, 2010), Belgium (Bogaerts et al., 2011), the Netherlands (Dorenbos and Froy, 2011) and Denmark (Mploy, 2011) for further details.

${ }^{6}$ Labour Market Development Agreement (LMDA) for insured unemployed, Labour Market Agreement (LMA) for uninsured unemployed, Targeted Initiative for Older Workers (TIOW) for older workers, Labour Market Agreement for Persons with Disabilities (LMADP) for the disabled.
} 
The 49 bilateral agreements under four different agreement templates that HRSDC has concluded with each province and territory (in Alberta with Alberta Employment and Immigration (AEI) and in New Brunswick with the Department of Post-secondary Education, Training and Labour (PETL)) are the principal accountability instrument in the federal-provincial relationship. They serve in principle to maintain a national policy framework and to oversee compliance of provincial performance with federal law (see below). In practice the exercise of federal oversight over policy is deferential to the provinces, some of which, like Québec, question the authority of the federal government to impose conditions on transfers for employment policy (Wood, 2010).

\section{Belgium}

In Belgium there has been a broad devolution of governmental competencies to the regions in the course of the constitutional reforms since 1980. Of the four countries compared Belgium exhibits the most far-reaching example of political decentralisation. The four Belgian regional PES organisations operate independently of one another and are responsible only to their own regional governments. The regional governments are fully free in defining PES goals and priorities, implementation structures, processes and programmes and finance their activities almost exclusively from regional budgets. In Flanders active policies are implemented primarily by its own regional PES organisation (VDAB).

Decentralisation of responsibility for active policies to the regions in Belgium has further complicated the already fragmented delivery system for employment services, which has by far the most complicated actor constellation at the implementation level of all of the case study countries. ${ }^{7}$ Not only the regional PES but also the federal government still plays an important role in labour market policy since it remains responsible for labour law and social security, including unemployment benefits, and regulates social assistance.

Although active programmes are primarily the responsibility of the regional PES, the federal government promotes the activation of the unemployed in various ways. The National Employment Office (NEO), which administers federal unemployment benefits throughout the country, ${ }^{8}$ conducts face-to-face activation interviews on a regular basis with the (insured) long-term unemployed and coordinates the Local Employment Agencies (PWA), which promote activation measures such as LEA jobs ${ }^{9}$ and service vouchers as well as other federal measures. The federal government also provides financial incentives for active measures by the regional PES for the insured unemployed or for special activation programmes for certain target groups (e.g. the long-term unemployed).

The Public Social Assistance Centres (OCMW) administered by the 308 local authorities are also actors in local labour market policy. The nationally regulated and municipally run offices provide income support to needy unemployed persons not entitled to social insurance benefits. Social assistance clients can

\footnotetext{
${ }^{7}$ See Bogaerts et al. 2011: Ch. 2 for a detailed account of "institutional crowdedness" in local implementation in Flanders.

${ }^{8}$ Jobseekers receiving national unemployment benefits through the NEO's 30 local offices are required to register with the regional PES. A co-operation agreement on activation of the unemployed between the national government and the regions requires PES intervention from the beginning of the unemployment spell. Importantly, the agreement also provides for regular data transmission between the federal and regional agencies, which enables the NEO to receive regular information on the activation and training history and conduct of the unemployed.

${ }^{9}$ A subsidised work scheme for the long-term unemployed who carry out additional local activities the need for which is not met by private firms, for example, household services, traffic control near schools, help with special events or seasonal farm labour.
} 
also receive other services in addition to income support, including employment services. ${ }^{10}$ Many OCMW centres, especially in larger cities like Antwerp with large numbers of social assistance recipients, develop their own activation policies using both federal activation measures as well as their own employment and training initiatives. ${ }^{11}$

There have been major attempts at the national level to foster local policy coordination, most recently the "partnership agreement on local employment policy" between the federal government, the Flemish Government and the local authorities (represented by the Association of Flemish Municipalities (VVSG)) in 2005. There are currently over 270 one-stop jobshops (Werkwinkel) in Flemish cities and municipalities. Jointly run by a steering committee of all partner organisations (the PES, NEO, PWA, municipality, GTB for the disabled etc.), they provide easily accessible services for jobseekers from the diverse actors at a single location. ${ }^{12}$ In most cases the jobshops provide only basic front line customer services and a colocated front office. Internal back-office procedures and systems remain separate which is an obstacle to operation. ${ }^{13}$

\section{Netherlands}

The Netherlands, like Denmark and unlike Canada and Belgium, is a unitary state and ultimate responsibility for active labour market policies lies with the national government. Implementation of active policies is, however, the responsibility of two different delivery systems based on national law: 1) the PES (UWV Werk Bedrijven) national agency for insured unemployed and, 2) the municipalities, which are responsible for the implementation of social assistance under the Work and Social Assistance Act (WWB). Since their management frameworks differ markedly they are discussed separately. ${ }^{14}$

The Dutch PES is a top-down, hierarchically organised and target-driven national PES organisation with a network of 11 district and 127 local office agencies supervised by the Ministry of Social Affairs and Employment. It provides basic services for the insured employed: gatekeeper and initial assessment, job matching and information services and some measures for the short-term unemployed ( $<3$ months). Those at risk of long-term unemployment are referred to the appropriate agency.

In 2004 the Work and Social Assistance Act increased emphasis on activation and a "work first" strategy for dealing with the unemployed on social assistance and introduced a new accountability framework in which the municipalities become financially responsible for implementation and are held accountable to central government goals primarily through financial incentives rather than by a top-down system of performance management with MBO, as in the PES. The principal goals of the new legislative framework and accountability structure was to stimulate municipalities to emphasise activation and reintegration of unemployed social assistance recipients and to create incentives for the municipalities to be more effective and efficient in implementing social assistance. More specifically, the goal was to reduce

${ }^{10}$ They implement federal law on social assistance (RMI: Right on Societal Integration) for needy persons, including the unemployed not eligible for NEO insurance-based benefits. Jointly funded by the federal government and the municipalities (50\%), their activities are only subject to minimal central regulation.

11 The organisation of these centers and the services provided vary greatly depending on the number of clients, possible local partnerships and local capacities.

${ }^{12}$ See Bogaerts et al., 2011, pp. 38-39. The jobshops, which are either based on local cooperation agreements or organised as nonprofit organisations, are staffed by their parent organisations, which also fund their operating costs.

${ }^{13}$ For example, the NEO, PES and Social Assistance Centers still have separate intake and different IT systems; welfare and PES use a different client to colleges (Struyven, 2010).

${ }^{14}$ See Dorenros and Froy, 2011, pp. 9-11 and SZW, 2008 for an overview of the two implementation structures. 
the number of benefit recipients by limiting inflow and promoting outflow through activation measures and combating abuse in the context of the new "work first" approach. The old municipal-based system was deemed to have placed more emphasis on entitlement rather than on obligations to seek and accept employment and to have provided too little incentive to reintegrate their clients because $90 \%$ of benefit costs were borne by the central government.

\section{Denmark}

Denmark is a unitary state, like the Netherlands, with a very strong tradition of implementation of public services by the local authorities. Until 2009 employment services for the insured unemployed had been provided by the national PES, the Labour Market Authority, through its own employment agencies co-located in municipal Jobcenters, in which the municipalities were responsible for employment services and benefits for unemployed on social assistance. After a short-lived experimental phase in 14 municipalities, the government gave the 91 local authorities complete responsibility for implementation in the fall of 2009, including services for the insured unemployed ("one-track system"). There is thus now a high degree of integration of a broad range of labour market, social and education services in the municipalities, which also are primarily responsible for local economic development. ${ }^{15}$

The principal goals of the delegation of responsibility for implementation to the municipalities were: 1) to establish a one-track delivery system serving all unemployed without regard to the type of benefits received: 2) to better align municipally based social assistance and services with national employment policy (Bredgaard, 2011; Mploy, 2011 ). Although responsibility for implementation has been delegated to the municipalities, the Minister for Employment remains responsible for national employment policy through the National Labour Market Agency and there is a strong commitment to national direction since labour market policy is a central element of national economic policy in the Danish model of "flexicurity". ${ }^{16}$ The traditional political saliency of labour market policy is augmented by the very strong policy emphasis of the current government on activation of the unemployed and a priority concern with coping with impending labour and skill shortages. ${ }^{17}$

The combination of municipal responsibility for implementation and strong central steering has led to considerable tension in the employment system. As in other countries, managers and social workers in municipal assistance offices had, as a rule, a different organisational culture - a more holistic and welfareoriented approach to their clientele. Moreover, the self-governing municipalities - many governed by opposition parties - are keen to resist what they perceive as encroachments on their own autonomy. From the government's perspective "this distance between political decisions and frontline staff implies, therefore, a risk that the intentions behind the reforms are not implemented fully" (Clausen and Smith 2007 in Bredgaard, 2011). ${ }^{18}$

Under the best of circumstances start-up problems for a new employment policy delivery system are normal. The circumstances of the Danish reform were also in other respects challenging (Mploy 2011):

\footnotetext{
${ }^{15}$ See Mploy, 2011: Ch. 2 for further details on the Danish employment policy system and recent reforms.

16 "Flexicurity" includes three essential elements: 1) flexible regulation of employment that makes it easy to dismiss workers in a downturn; 2) income security based on generous social benefits in case of unemployment; 3 ) strong emphasis on active policies to re-integrate the unemployed and prevent abuse of benefits. By international standards Denmark has low employment protection, very high wage replacement levels (but of limited duration) and a very high level of expenditure for active policies.

${ }^{17}$ The focus is not only on the unemployed but also on those who have withdrawn from the labour force and are on other social benefits (e.g. early retirement, disability pensions or sickness benefits).

${ }^{18}$ See Bredgaard, 2011 for a discussion of the political context of the 2009 reform.
} 
1. The recent structural reform of local government, which reduced the number of municipalities from 271 to 98 while extending their responsibilities, had not yet been mastered in some affected municipalities;

2. The reform gave the municipalities responsibility for employment services for a new client group, the insured unemployed, for the first time. They also had to integrate staff from the former local PES offices;

3. Almost immediately the new system was impacted by an unprecedented economic crisis with a sudden surge in unemployment. 


\section{DECENTRALISATION AND ACTOR CONSTELLATIONS}

All four countries examined represent cases of political decentralisation of responsibility for active policies; however the national settings and paths to decentralisation differ. In Canada this took place within a traditional federal system of government whereas in Belgium it was part of a broader regionalisation process. In both cases the decentralisation of responsibility for active policies was a response to separatist tendencies and tensions between national and regional authorities. Whatever specific policy improvements policy makers may have hoped to achieve, enhanced provincial or regional control was an end in itself.

The Netherlands and Denmark are, by contrast, unitary states in which political decentralisation has taken the form of municipalisation of responsibility for active measures for both the insured unemployed and those on social assistance in Denmark and in the Netherlands only for the latter. A principal motivation for the reform in both was to mobilise municipal support for national employment policies as well as to improve efficiency and effectiveness. In both countries governments emphasising a work first approach perceived municipal administration of social assistance as giving too little emphasis to activation and control of abuse. In both cases the reforms represent increased centralisation in the sense that they impose a more rigorous national accountability framework on municipal practice than was previously the case. ${ }^{19}$

Only the Netherlands still retains a national PES responsible for active measures (and unemployment benefits), if only for the insured unemployed. Political decentralisation and organisational decentralisation in the form of management by objectives are not mutually exclusive. The regional PES organisations in Alberta and New Brunswick in Canada and Flanders in Belgium combine devolution to the regional level with internal systems of performance management.

Actor constellations in labour market policy are complex and the PES is increasingly only one major player. It is useful to distinguish between different types of employment services when comparing actor constellations: active and passive services and services for the insured and the uninsured unemployed, in particular on social assistance. These services can be provided by organisations at different levels of government e.g. by a national PES, at a regional level (provinces, states, regions) or by local authorities (municipalities, counties). In most countries private providers are commissioned to provide some of these services.

Opinions differ on whether responsibility for policy and implementation of these services should be concentrated in one actor at one level of government or whether division of labour among more specialised agencies is appropriate. The answer of course depends on national circumstances and traditions as well as priority policy concerns. It is clear, however, that fragmentation in responsibility for the design and implementation of labour market policy gives rise to greater cooperation challenges, especially when different levels of government are involved. As the four countries in our comparison illustrate, decentralisation of active labour market policy is often accompanied by new problems of cooperation at the implementation level.

In Canada (Alberta and New Brunswick) decentralisation of federal employment programmes to the provinces led to a more integrated delivery system under the auspices of the provincial PES (AEI and PETL), which integrates a broad spectrum of activities (e.g. employment programmes for insured unemployed, social assistance recipients, youth counselling etc.) within one organisation responsible for

\footnotetext{
${ }^{19}$ For the background and policy rationale of the reforms see SZW, 2008; de Koning, 2009; van B erkel, 2009 for the Netherlands and Mploy, 2011 and Bredgaard, 2010 for Denmark.
} 
most employment services. Only benefits for the insured unemployed are administered separately by the national government through its own local offices as well as a number of special federal programmes that have not been devolved. ${ }^{20}$ Because the organisation of implementation within the provinces is solely at the discretion of the provincial government, it can vary considerably throughout Canada (Wood, 2010).

In Belgium institutional fragmentation of responsibility between different local actors subordinate to different levels of government is greatest among all the countries studied and leads to special problems. In Flanders employment policy is implemented not only by the regional PES and the 30 local offices of the National Employment Office but also by the municipalities, which often have their own local employment departments in larger cities (e.g. Antwerp), and the municipally administered Public Social Assistance Centres. In particular, the increased emphasis by the federal government on the activation of unemployment benefit recipients through the NEO offices has blurred the boundary between regional active programmes and federal responsibility for social security.

In the Netherlands the PES and the municipalities with their job centres and benefit payment offices are now responsible for all employment services for the insured and uninsured unemployed respectively. Although service delivery is still divided, recent reforms have considerably simplified local implementation of services. Through the promotion of local 'work squares' (werkplein), local partnerships between the PES and the municipalities on a voluntary basis, government policy is now addressing one of the principal remaining cooperation problems in labour market services, although coverage is still incomplete and the level of cooperation varies locally.

Denmark is the only one of the four countries examined that has combined decentralisation in employment policy with a concentration of responsibility for policy and for implementation of active policies respectively in one actor and one level of government. The Minister of Employment is responsible for all aspects of employment policy and the municipalities with their job centres for implementation of active policies for both the insured and uninsured unemployed, as well as for social assistance benefits through separate municipal payment offices. Trade-union unemployment insurance funds remain responsible for benefits for the insured unemployed, also conducting initial activation interviews since 2007.

\section{Accountability frameworks in four decentralised delivery systems}

In the following we discuss and compare the accountability frameworks in the four cases of political decentralisation.

It is noteworthy that in two of the four cases studied, decentralisation in the context of multi-level governance entails not only greater regional or local responsibility for implementation but also a devolution in responsibility for policy. In both Belgium and Canada primary responsibility for active labour market policy and implementation has been devolved to the regions or provinces and the central government now plays only a limited role, although the national government retains responsibility for benefits for the insured unemployed in both countries. ${ }^{21}$ By contrast, in the Netherlands and Denmark both unitary states, overall responsibility for labour market policy clearly remains with the central government despite decentralisation of implementation of all employment services in Denmark and of services for social assistance recipients in the Netherlands.

\footnotetext{
${ }^{20}$ Federal programmes for youth, the disabled and aboriginal persons.

${ }^{21}$ Devolution of responsibility for active labour market policy is more far-reaching in the Belgian case; in Canada the provinces control programme design and delivery, subject only to broad national guidelines. The level of federal funding is set by the central government.
} 
The accountability frameworks and management system of the four countries differ markedly and are in several respects noteworthy. Traditional forms of performance management as management by objectives, once the principal management framework for reconciling accountability and flexibility in national PES organisations (Mosley et al., 2001), have become less important, softer, weak or non-existent in delivery systems that have decentralised responsibility to subordinate levels of government. In Belgium there is no national performance management framework. The regional PES organisations are accountable only to their own regional government. ${ }^{22}$ In Canada there is still an accountability relationship between the provinces and territories and the federal government based on the conditional allocation of federal funds on the basis of intergovernmental agreements. In practice, however, the performance accountability relationship is relatively weak.

Only the Dutch and Flanders (Belgium) regional PES organisations, responsible for the insured unemployed, approximate the MBO model with central goals and quantitative targets at all organisational levels, systematic monitoring and assessment of performance against targets, although in both cases flexibility of regional and local managers is very limited. In Alberta and New Brunswick (Canada) there is a provincial performance contract between the national government and each provincial PES, with internal steering within each PES based on an intensive and participatory planning process and budget controls rather than on quantitative targets. In Denmark the municipalities develop their own employment plans. While obligated to include the minister's annual goals, they set their own quantitative targets. Performance management is now conceived largely as a dialogue process in which the employment regions challenge them to set ambitious targets.

The municipalisation models for all employment services in Denmark and for social assistance in the Netherlands are novel because they either no longer rely on central performance management (the Netherlands) or only in weakened form (Denmark), relying instead primarily on economic incentives to align the actions of the decentralised actors responsible for policy implementation with national goals. ${ }^{23}$

\section{Canada}

\section{Federal-provincial relationship}

In Canada the federal government strives to maintain a minimal national accountability framework through the bilateral agreements with the provinces and territories. The federal-provincial relationship is in principle a contract relationship with each province in which the federal government makes funding available from the unemployment insurance fund and from general revenues to the provinces to implement labour market programmes under their control. In general the agreements specify the amount of funding available, the eligible clients and, in very broad terms, the types of measures and services that can be funded. Each of the four template agreements has its own accountability framework, which differ in detail from one to the other, with the potential for variations between provinces. Each agreement has its own funding.

\footnotetext{
${ }^{22}$ The Flanders regional government derives its revenues for active measures and other responsibilities from 'shared taxes' with the federal government and not from central government appropriations, in addition to its own tax revenues (Leibfritz, 2009). Based on its continuing responsibility for social security, the central government does fund some special activation measures provided by the PES, for example, for the longterm unemployed to which conditions are attached.
}

23 In contrast to the Netherlands, the Danish labour market authority still maintains traditional MBO-type management tools, including a national system of continuous performance monitoring and close oversight by the PES employment regions offices. It is, however, in principle a dialogue-based form of performance management vis-à-vis the municipalities without explicit powers to direct or sanction them. 
The Labour Market Development Agreements, the first and most important type, limit eligibility for more intensive active programmes (e.g. training) to unemployment benefit recipients, whereas general employment services are available to all unemployed. The agreements specify in general terms requirements pertaining to fiscal and legal accountability including the obligation to submit an annual plan three months before beginning the fiscal year, setting out in particular the allocation of funds by type of measure, an annual audited financial report on the costs incurred for each type of programme, the obligation to report data on claimants for national statistical purposes, as well as joint policy reviews and evaluations. In many provinces a LMDA Management Committee in which provincial and federal governments are equally represented provides for ongoing coordination and interpretation of the agreements (Wood, 2010).

All the Labour Market Development Agreements include three core indicators: the number of benefit claimants in provincial measures, the number of claimants entering employment, and cost savings for the unemployment insurance system. The choice of indicators reflects the federal government's priority concern with reducing the number of benefit claimants and costs for the unemployment insurance system. Although the federal Labour Ministry announces national targets for the indicators, there is no top-down disaggregation of these targets to the provincial level. Each province develops its own targets as part of their annual planning process and in consultation with local federal officials, and these are aggregated to the national level (Wood, 2010). ${ }^{24}$

The provinces are obligated to provide data to the federal government on claimants' participation in their programmes which feeds into an annual national Employment Insurance Monitoring and Assessment Report. The quality of the national data is, however, problematic due to differences in definitions, reporting practice and IT systems among the provinces. There is thus no robust quantitative benchmarking and controlling of provincial performance at the federal level (Wood, 2010). ${ }^{25}$

The federal-provincial relationship can be described as accountability light in the sense that it is largely focused on legal and fiscal accountability, that is, control of the legality and correctness of expenditure of federal financing, with strong deference to the provinces and territories in shaping policy and programmes. There is no system of performance management that strives to impose national policy guidelines on the active policies of the provinces and territories, except for the federal priorities implicit in the earmarking of funds for the insured unemployed and other target groups. There is complete flexibility in allocating funds within the frameworks of the several bilateral agreements; LMDA for insured unemployed, LMA for uninsured unemployed, TIOW for older workers, LMADP for the disabled which are not earmarked for specific programmes. The principal inflexibility from the point of view of the provinces is that they cannot transfer federal funds between funding streams for the different client groups, which complicates the budgeting process. However since funding levels have been adequate and provincial resources are also available, to date this has been a relatively minor problem. ${ }^{26}$

\footnotetext{
${ }^{24}$ The Labour Market Agreements for unemployed persons who are not insurance benefit claimants are generally similar but specify a broader array of ten indicators to be reported, although provincial targets do not have to be agreed with the responsible national ministry.

${ }^{25}$ In this respect the federal-provincial negotiations over the first LMDA agreement were paradigmatic: "A key Alberta objective was to minimise the degree to which the province reported to the Government of Canada. A key federal objective was to get an agreement in the first place, which meant that the relationship imperatives trumped the accountability imperatives" (Wood, 2010, p.65).

${ }^{26}$ For example, federal funding accounts for only about $50 \%$ of expenditure for active policies in the province of Alberta (Wood, 2010, p.83).
} 


\section{Provincial - regional - local relationship}

In Canada it is the provincial management system that is decisive for reconciling accountability and flexibility at the regional or local levels. The processes used in Alberta and New Brunswick are relatively similar, but there are some key differences.

The Alberta Employment and Immigration PES activities are primarily motivated by and organised around an annual business plan which outlines the vision, mission, strategic priorities, core businesses, goals, performance measures and targets for all ministry programmes. The business plan is the centre piece of what, at first glance, appears to be a tightly run provincial MBO-type accountability framework that is strongly target-driven. This first impression is, however, misleading. Although the Alberta PES does state its goals and performance measures in an annual business plan, which is the central point of reference for the budgeting and planning process within the organisation, provincial level targets are not disaggregated to the regional and local levels, as occurs in more formalised systems of management by objectives, but remain soft targets. Instead management relies primarily on an intensive top-down planning process, rolled-up operational planning, intensive personal interaction and motivation and professionalism of staff. There is direct and intensive communication between the central manager for service delivery and the six regional directors, who in turn communicate with their 59 local offices. There are informal assessments at regional management committee meetings but no formalised process, benchmarks or sanctions.

The management information and other monitoring data available to provincial managers appears adequate for the Alberta management strategy, which does not use quantitative targets internally, but relatively underdeveloped in comparison with systems in some PES organisations (e.g. the Netherlands, Flanders, and Denmark). The provincial PES management for service delivery receives reports on a quarterly basis on regional and local office performance in relation to the business plan, which are apparently not from IT-based client management software and reporting system but generated, at least in part, by hand. Control of performance at the programme and provincial level seems to rely mainly on monthly surveys (Work Outcomes Reporting Project) and process data ("Mobius"). ${ }^{27}$

The Alberta management model is unusual in comparative perspective and appears to offer an alternative to more target-based MBO-type management systems in that it permits more regional and local flexibility without sacrificing accountability. One explanation for the lower level of formalisation in the Alberta Employment and Immigration management model is that it is a provincial government department rather than an autonomous executive agency operating under a contractual management agreement. Moreover, the size of its total staff is relatively small (ca. 1 500) in comparison with other PES organisations. This makes possible short chains of command, intensive communications and personal relations between management levels and between regional directors and local staff that is not possible in a larger, more centralised organisation. An essential prerequisite is, of course, the Canada-wide devolution of responsibility for employment services to the provincial level.

Although there are important differences in the size of Alberta and New Brunswick, their relationship to the federal government as well as the PES internal organisation and management structures are broadly similar. Alberta, a relatively wealthy province, finances a significantly larger share of provincial labour market programmes from its own resources (50\% vs. $20 \%$ in New Brunswick). They also differ in important respects in the array of services which they provide and how they are implemented, for example, less contracting out of service provision in New Brunswick and greater reliance on the non-profit sector (Wood, 2010).

\footnotetext{
${ }^{27}$ A new client service IT system, Mobius, is being introduced but its usability for performance management is limited and there have been problems with data quality and reporting (Wood, 2010 p.103).
} 


\section{Belgium}

Since the Flemish government is constitutionally responsible for economic and employment policy there is no explicit accountability relationship to the Belgian federal government. ${ }^{28}$ The principal issue in the federal-regional relationship is rather that of cooperation in an employment policy system in which labour law and social security remain federal responsibilities while (most) employment services are regionally managed and implemented. ${ }^{29}$

The accountability framework in Flanders is based on MBO-type management agreements between the responsible ministry and the PES, and within the PES between it and its sub-regional and local offices. Although responsibility for public employment services in Belgium has been devolved to the regional level, the Flanders regional PES itself (VDAB) is a highly centralised, hierarchical and target-driven agency with 13 sub-regional directorates and six provincial vocational training centres. ${ }^{30}$ The Flemish PES is an autonomous executive agency that is governed through a rolling multiyear management agreement with the Flemish government. On the basis of its contract with the Flemish government, it develops a business plan containing its strategic and operational objectives for the current year. The strategic goals and targets are largely defined at the regional level with only limited input from the Flemish (sub-) regional and local PES offices.

In the 2011-2015 management agreement the labour market target indicators for job seekers are (for the first time) almost exclusively defined in terms of outflow rates into work for seven categories of jobseekers defined by age, duration of unemployment, distance from the labour market or having been displaced due to restructuring. ${ }^{31}$ In addition to outcome indicators there is a strong emphasis on customer satisfaction surveys for job seekers, employers, course participants etc. (see Bogaerts et al., 2011).

The Flemish PES has a well developed IT-based monitoring system that provides the central office with data on a monthly basis, tracking performance against targets. There are no direct financial or other consequences for the sub-regional offices that fail to meet targets but district managers are expected to explain why targets could not be reached in the context of a dialogue based "scorecard" assessment. Managers who fulfil their targets do receive a small bonus in recognition of their good performance (Bogaerts et al., 2011).

District (sub-regional) and local offices have little or no budget flexibility. There are central budgeting earmarked funds based on the national management agreement, largely for staff and in-house services, and thus little room for manoeuvre in developing local approaches District managers can more easily allocate staff resources than financial resources for local cooperation. An exception here is the "local project

${ }^{28}$ Since 2004 a single minister in the Flemish government is responsible for both employment and education and training, which facilitates, in principle, co-ordination between these policy areas.

${ }^{29}$ There is, moreover, an implicit incentive problem in that the federal government bears the costs of unemploymentthrough the contribution-based social security system but has no direct control over regional policies to combat unemployment (and regional governments have only limited financial incentive to do so). The federal response to this dilemma has been to increase activation activities with its own long-term unemployed clients and to even provide financial incentives for Flanders to enroll them in active programmes. Such inter-regional financial transfers through, inter alia, the social security system are an important national issue in Belgium.

${ }^{30}$ The local offices primarily provide general counseling and placement services for jobseekers and employers and are responsible for coordinating their services with other local labour market actors.

${ }^{31}$ There are additional "strategic" targets for other areas (career services, services for employers, labour market training outcomes or partnerships). 
programme" budget which is, however, small. ${ }^{32}$ District and local offices cannot contract out services directly but have to utilise external providers whose services are defined and managed by the PES central office. District offices can request central tenders for specific sub-regional purposes; however this has to be financed out of their own limited local programme budget. Jobseekers can also be referred to the VDABrun training centres if they have training needs (Bogaerts et al., 2011).

In summary, the Flanders PES allows little operative discretion for its separate sub-regional offices to allocate resources and adapt programmes to specific local needs or to engage in joint cooperative projects with other actors at the local level. Although Flanders is not a large territory, it is not one labour market but includes a number of quite diverse labour market areas with distinctive problems and actor constellations that make it necessary to adapt general policies to specific local needs.

For example, local labour market actors in interviews in the Kortrijk area in West Flanders, a region with low unemployment, were concerned primarily with meeting labour shortages and would like to have more pro-active and employer-oriented policies, e.g. skills training to meet skill-shortages, recruitment from outside the local area. However, PES programmes and resource allocations are, in their view, oriented primarily toward reintegration of the unemployed and problem groups and thus were not adequately serving their local needs. ${ }^{33}$ In Antwerp, an area with a large concentration of problem groups, municipal cooperation with the local PES office was said to be difficult because of centralisation at the Flanders level which makes decision-making too slow, and its insistence on doing things according to it "own plans and way."

It should be noted that the VDAB is currently undergoing a major internal reorganisation to create a more efficient management system. A new intermediate level of five provincial offices is planned, which will have greater autonomy and input into central decisions than do the current 13 district offices. The details of the reform are being finalised (Bogaerts et al., 2011).

There are, in conclusion, two marked features of the accountability framework for labour market policy in Flanders. First, although there is an almost complete decentralisation of responsibility for employment services in Belgium to the regions, the Flemish regional government has established a highly centralised PES based on a relatively stringent model of management by objectives that leaves its own district and local offices very little flexibility to adapt policies to local circumstances or to engage in cooperative actions with the other actors in local implementation. Second, fragmentation in policy-making and implementation between levels of government (federal, regional, municipal) leads to an extremely complex actor constellation ("institutional crowdedness") that blurs political accountability and confronts local implementation with marked co-operation challenges.

In both Canada (Alberta and New Brunswick) and especially Belgium (Flanders) decentralisation at the national level has not been translated into correspondingly greater flexibility at the sub-regional and local levels at which policy implementation occurs, although policy making is now closer to the operative level and the lines of communication are shorter than in the past. Within Alberta and New Brunswick there is somewhat greater flexibility in implementation (programme mix, work organisation and contracting out) especially for regional offices, whereas district and local offices have less operative discretion in Flanders.

In both cases political decentralisation at the national level is combined with highly structured and target-oriented PES organisations based on an MBO type accountability framework. They are, in this sense, well-managed but largely self-referential, that is, focused on attaining their own organisational

\footnotetext{
${ }^{32}$ According to local interview partners this makes up only about $3 \%$ of the budget.

${ }^{33}$ There was diffuse dissatisfaction with the degree of centralisation within Flanders and the "lack of confidence in the local level."
} 
goals. In both cases the MBO style is top-down. ${ }^{34}$ As noted above, the internal MBO style in Alberta PES is distinctive, relying on an inclusive planning process and intensive personal interaction between organisational levels and staff rather than on quantitative targets.

While both are self-referential and lack sufficient flexibility at the sub-regional or local level, this flexibility deficit is more problematic in Flanders than in Alberta and New Brunswick. In these cases the regional PES is itself responsible for most elements of labour market policy (except unemployment insurance) benefits, whereas in Flanders even responsibility for active policies is institutionally fragmented.

\section{Netherlands}

In the Netherlands there are two delivery systems for employment services depending on benefit eligibility, the national PES (UWV Werk Bedrijven) for the insured unemployed and the municipally implemented Work and Social Assistance Act for the unemployed on social assistance. Although both systems are based on national law and largely nationally funded, their accountability frameworks differ markedly.

\section{PES for the insured unemployed}

The UWV is a traditional top-down, hierarchically organised and target-driven national PES organisation. Targets are set centrally by the Labour Ministry in consultation with the PES national and district offices and disaggregated to the local level. The PES has standardised data definitions and collection, operating procedures and national monitoring and evaluation of the performance of local agencies. When performance falls short of targets, managers are expected to explain the failure and discuss the problems to be resolved. There are no direct sanctions for failure to meet agreed targets but there may be career consequences for local office manager who consistently fail to meet targets (Dorenbos and Froy, 2011)

PES offices receive a global reintegration budget from the national PES based on the projected number of unemployment benefit recipients and other factors from which client services have to be financed. Funds are not earmarked for specific programmes but, in 2010, had to be allocated for services to different target groups based on the duration of unemployment spells, with most resources earmarked for the long-term unemployed until the end of $2010 .{ }^{35}$ Earmarking funding for specific target groups limits the scope of cooperation with the local authorities responsible for social assistance ${ }^{36}$ (Dorenbos and Froy, 2011)

Local PES offices have a broad range of labour market programmes at their disposal in addition to the universal services available to all clients. They can, in principle, choose whether to provide services inhouse or to contract out to private reintegration companies but external contracts have to be tendered through the central PES office. In most cases, however, these are standardised programs and the local or regional PES offices have no direct control over the programme contents or selection of the provider. Changes or innovations in the standardised contract instruments are difficult and time-consuming to

\footnotetext{
${ }^{34}$ Some MBO-type PES organisations permit much more local flexibility, e.g. in Germany.

${ }^{35}$ Of the total 2010 reintegration budget of $€ 126$ million $€ 86$ million had to be spent on services for the long-term unemployed (> 12 months), 20 million for those unemployed from 3 to 12 months and 20 million for the short-term unemployed.

${ }^{36}$ Among other reasons because eligibility for support is not based on clients' distance from the labour market but on the duration of the unemployment spell.
} 
achieve. Centralised tendering results in typical complaints about standardised services, long time lags and lack of influence over the choice of providers $^{37}$ (Dorenbos and Froy, 2011)

\section{Municipal social assistance and employment services}

As in many countries the municipalities have long played a central role in providing social assistance to needy unemployed persons, and since the 1980s they have been increasingly active in providing reintegration assistance to their unemployed clients. In 2004 the Work and Social Assistance Act increased emphasis on activation and a "work first" strategy for dealing with the unemployed on social assistance, and it introduced a new accountability framework in which the municipalities become fully responsible for implementation and are held accountable to central government policy goals largely based on financial incentives. ${ }^{38}$

Instead of central performance management the Dutch accountability framework relies almost exclusively on financial incentives for the municipalities. In terms of agency theory, instead of targets, monitoring and sanctions to control agents' behaviour, financial incentives are supposed to align the interest of the agent with those of the principal.

Social assistance is nationally financed from general revenues of the central government. Dutch municipalities receive two different budget allocations: the income budget for benefits and the work budget for reintegration activities. The income budget for social assistance payments is a fixed sum. Municipalities can gain if they succeed in spending less and lose funds if their expenditure is greater. Since benefit eligibility is centrally regulated, they can only affect their financial outcomes by providing better employment services, stricter enforcement of eligibility requirements, or both. This financing system is intended to give the municipalities a strong incentive for successful labour market integration of employable social assistance recipients. It also provides an incentive for more restrictive enforcement of benefit requirements in accord with the legislation's "work first" approach. ${ }^{39}$

\section{Economic incentives $^{40}$}

The allocation for benefit payments to the municipalities is a fixed sum based on statistical projections of the expected number of beneficiaries. For the larger municipalities (> 40000$)$ it is based on a statistical model utilising population characteristics; for small municipalities $(<25000)$ historical data is used; for intermediate size municipalities a combination of the two methods is used. Even small municipalities are under pressure to improve performance since the national development of the volume of social assistance determines the national budget of which they receive a prorated share (SZW, 2008; van Geuens and van Gent, 2008).

If the municipality's benefit payments exceed this amount, they have to bear the additional costs; if their social assistance payments are less, they may use these funds for other municipal purposes. If their deficit exceeds $10 \%$ of expenditure for income support, municipalities can apply to receive a supplement.

\footnotetext{
37 There was a widespread opinion in the local UWV offices that there were important local needs that they were unable to address through the standardised employment programmes available. They attributed this in particular to programme design features such as regulations pertaining to the length of training or the prescribed mix of individual and group components.

${ }^{38}$ For an official overview of the reform of social assistance see SZW, 2008.

${ }^{39}$ Social courts and client organisations can provide some protection against abuse.

${ }^{40}$ For an overview see SZW, 2008; Dorenbos and Froy, 2011.
} 
There are no central performance goals or targets for municipal employment services. Within the framework of national law, municipalities are free to develop their own reintegration strategies and programmes. The municipal boards that oversee the social service departments formulate their own goals and targets and develop appropriate indicators. There is no national monitoring of municipal employment services and their outcomes. ${ }^{41}$ Even municipal obligations to provide information for national statistical and accountability purposes have been largely eliminated as part of the decentralisation reform ("dereporting") (van Geuens and van Gent, 2008). ${ }^{42}$ Central government appears to have very limited information on what the municipalities actually do and how effective their active programmes are.

\section{Active policies}

The reintegration budget is a global budget and the municipalities are fully free to use it for whatever programmes they deem appropriate for their clients. An additional element of flexibility is that, if unspent, up to $75 \%$ of the reintegration budget can be carried over to the following year. The municipalities have made extensive use of this option and accumulated sizeable budget surpluses every year until 2008 (Dorenbos and Froy, 2011). ${ }^{43}$

The municipalities have complete freedom to decide what programmes they use, to adapt them to local needs or and to design programmes as they see fit. Municipal programmes can thus vary greatly, although in practice programmes are quite similar and there seems to be too little to use of the new flexibility available. Work organisation and work processes are likewise completely at the discretion of the municipalities.

Municipal staff are local employees and staff can be recruited or reallocated at the discretion of the municipality. The municipalities are free to either implement reintegration services and programmes themselves or to contract them out themselves to external providers, which they do to a large extent for specialised reintegration programmes. ${ }^{44}$ (Dorenbos and Froy, 2011)

In contrast to reintegration activities and programmes, benefit entitlement is regulated by national law and implementation procedures are subject to greater central regulation. ${ }^{45}$

On the whole the municipalities express a positive view of the new financing system and the flexibility they have but municipalities that spent more than allocated were critical of the distribution model (van Geuens and van Gent, 2008; Dorenbos and Froy, 2011). Some argue, for example, that the model penalises them for past good performance in reducing dependency. Moreover, the distinction

${ }^{41}$ Because municipal agencies use different software, there is no common national IT system.

${ }^{42}$ There is some voluntary monitoring and comparison of performance conducted by municipal associations, for example by DIVOSA, an association of managers for work, income and social issues (Dorenbos and Froy, 2011).

43 Since 2009 the reintegration budget has been merged into a broader municipal "participation budget" for reintegration, adult education and social inclusion. Thus far municipalities appear to have made little use of this option (Dorenbos and Froy, 2011).

${ }^{44}$ Until 2007 they had been obligated to contract out reintegration services to external providers.

45 Although specific regulations governing the implementation process, for example routine checks on benefit applications have been greatly reduced or eliminated, there are still current issues. For example, the Ministry for Social Affairs and Labour, with a few exceptions, excludes categorical decisions on benefit entitlement, such as the exemption of single parents with child care duties from the obligation to accept work, whereas the municipalities regard this as administratively burdensome and a relic of past centralist practice (SZW, 2008). 
between the income budget for benefits and the reintegration budgets are, in practice, unclear and some municipalities have used "remarkable construction to relieve the income part at the expense of the working part" (van Geuens and van Gent, 2008, p.5).

Like all such regression models, it rests on the assumption that the residuals, i.e. the difference between estimated and actual expenditure, for social assistance reflect differences in policy rather than factors not included in the model, which is unlikely. The Ministry has sensibly taken this into account by imposing a ceiling of $10 \%$ on the redistributional impact of the model. Furthermore, as noted above, the model is fully applicable only to the larger municipalities since the impact of incidental factors increases with declining scale. Finally, municipalities with deficits can apply for supplementary funds if they can show special circumstances, which were approved in most early cases. The model seems on the whole plausible in providing an incentive for active measures and combating abuse, although unfair in some individual cases. The possibility of receiving supplementary funds, the result of political lobbying by the municipalities, can mitigate unfairness.

Although the financing systems gives municipalities a strong incentive to control benefit expenditure by activation measures and stricter control of eligibility in accord with government policy, these incentives may be short-sighted if they lead to creaming and dead weight by focusing active measures on persons with the least distance to the labour market. Moreover, the broader concerns of labour market policy, such as training to meet skill shortages, may not be well served by one-dimensional incentives.

\section{Denmark}

In the new delivery system far-reaching decentralisation of responsibility for implementation is coupled with a strong emphasis on policy accountability to central policy goals and minimum service standards. Although regulated by national law and nationally funded, the municipal Jobcentres are agencies or departments of the self-governing municipalities and, unlike the former local PES agencies, neither part of the PES nor subject to its hierarchical policy direction. In order to ensure central accountability in the context of political decentralisation, the 2009 reform establishes a complex regulatory and management framework that relies in particular on financial incentives to induce compliance with national policy. The principal elements of the central accountability framework are:

1. Reliance on financial incentives instead of administrative rules and supervision since the local authorities and their Jobcentres are not directly subject to ministerial directives or to those of the National Labour Market Authority;

2. Prioritisation of municipalities' employment efforts through organisational requirements or Jobcentre governance;

3. Parallel system of dialogue-based performance management.

In Denmark, like in the Netherlands, financial incentives now play a central role in securing accountability in the context of political decentralisation.

\section{Economic incentives $^{46}$}

Municipal finances are based on transfers from the central government and on revenues from local taxes. In the area of labour market policy there are two principal financing streams: (1) block grants for municipal administrative expenses; (2) state reimbursements for expenditure for income support benefits and for active measures (Mploy, 2011).

\footnotetext{
${ }^{46}$ The economic incentives described here are those in force at the time of our research in the fall of 2010.
} 
The municipalities receive block grants for administrative expenses for carrying out a range of national programmes that they implement, including the operating expenses of their Jobcentres. Noteworthy here is that these funds are entirely flexible and can be shifted between different local policy areas. However there is a national "service ceiling" that limits the amount by which municipal administrative expenditure is allowed to increase. The combination of complete flexibility in allocating block grant funds to different policy areas and the service ceiling means that there is a strong competition between municipal policy areas.

State grants and refunds. In general the financing system for labour market policy compensates the municipalities as a group for their expenditure for income support and, up to a ceiling, for active measures; however individual municipalities may gain or lose funding depending on the results they achieve. The financing system is extremely complicated and we can here only attempt to explain and illustrate the general principles and the types of incentives that arise.

In general there are two financial streams: (1) state refund rules (municipal co-financing) and (2) direct state grants.

1) State refunds: The level of state reimbursements for both social benefits and employment measures depends on a number of other factors related to the activation process and to whether and what type of activation measures they participate in:

- After an initial period the state refunds $65 \%$ to $75 \%$ of the costs of unemployment benefit if the unemployed person is in an activation measure and $35 \%$ to $50 \%$ if not. ${ }^{47}$

- Municipalities that fail to meet certain minimum service requirements prescribed by law are required to bear $100 \%$ of the costs of benefit payments for the individual concerned for the period in which they are not in compliance. ${ }^{48}$

- The state reimbursements for active measures also vary depending on the type of active measure. The state normally refunds $50 \%$ of the operating costs up to a ceiling ${ }^{49}$ but the rate is higher for certain types of measures favoured by the government, for example, wage subsidies $(65 \%$ to $75 \%$ ), adult apprenticeships (100\%). The government also encourages use of external contract services by providing a financial incentive. ${ }^{50}$

2) State grants: A second component of state funding of costs for income support payments is based on direct grants. They are calculated on the basis of expenditure in the previous year and projections for the current year. The grants provide an economic incentive because they are based in part on the average change in unemployment in the region (Bredgaard, 2011). Municipalities thus can gain financially if they succeed in placing benefit recipients into (regular) employment. These incentives serve two principal purposes from the perspective of the state: they induce municipalities to give employment policy high priority and they steer local policies toward

\footnotetext{
${ }^{47}$ The initial period was 18 weeks in 2010. Refund rates depend in part on the kind of benefit the unemployed person is receiving.

${ }^{48}$ For example, preparation of an online CV within three weeks of initial registration, an initial job interview within three months and every three months thereafter, an activation measure after nine months of unemployment at the latest (youth within one month).

${ }^{49}$ The ceiling is based on a rate per full-time benefit recipient set by the government annually and the number of unemployed. The state co-finances $50 \%$ of expenditure up to the ceiling.

${ }^{50} 50 \%$ of the administrative costs, which normally have to be borne by municipalities.
} 
conformity with national policy guidelines. "Good results" in the sense of national guidelines or above average performance generate revenues which can also be used for other municipal activities, whereas "poor results" require a higher level of municipal co-financing, eventually at the expense of other municipal programmes and activities.

\section{Prioritisation of employment policy}

In addition to financial incentives, the new employment policy framework also seeks to make employment policy a priority local concern through central requirements for the governance of municipal Jobcentres. This is considered necessary because municipalities have a broad range of responsibilities that can compete with employment policy (e.g. education, culture, child and youth programmes, local economic development etc.) Moreover, the funds allocated from the national level for the administration of employment services are not earmarked and can in principal be used for other local administrative tasks. Finally, savings in labour market policy can be used for other municipal purposes. On the other hand, if they incur higher expenses for labour market policies these must be financed from other general municipal funds. The transferability of funds in the municipal budgets between different policy areas means that employment policy competes broadly for resources at the local level (Mploy, 2011).

The main statutory requirements are:

1. The job centre must be separate from the administration of benefit payments;

2. It must be managed by a separate committee under the municipal council $;{ }^{51}$

3. The committee chairman also serves as the ex officio chairman of the Local Employment Council, the principal advisory body for the local job centre with the aim of promoting the widest possible cooperation with other local actors.

\section{Performance management}

Although the municipal job centres are, in the first instance, accountable to their own municipal authorities, there is a parallel dialogue-based system of performance management overseen by the four regional offices of the National Labour Market Agency (PES). This is based on a small number of core national priorities, strong reporting requirements, frequent management dialogue and public transparency of quantitative results rather than on centrally determined quantitative targets for municipal performance. Each year in early spring the Employment Minister announces three to four national policy goals for the coming year in areas deemed of special importance. The goals are very broad, focusing on reducing longer-term unemployment (> three months) and receipt of income benefits. ${ }^{52}$ The central focus of the performance management process on the goals of the Employment Minister serves to achieve a coherent national employment effort across all 91 job centres (Mploy, 2011)

\footnotetext{
${ }^{51}$ Alternatively, the municipality may elect to give responsibility to the financial committee under the chairmanship of the mayor.

${ }^{52}$ For 2011 these goals were:

- $\quad$ Minimise the number of unemployed with more than three months of continuous unemployment

- $\quad$ Minimise the number of people under the age of 30 who receive unemployment and social security benefits

- $\quad$ Minimise the number of persons on permanent income support schemes

- Minimise the number of non-western immigrants who receive public benefits.
} 
The ministry targets are concretised in an annual performance agreement between the Minister, the PES and its regional offices and the (advisory) regional Employment Councils. ${ }^{53}$ For each of the minister's labour market goals the PES articulates national quantitative targets that should be achieved collectively by the activities of the municipal Jobcentres. ${ }^{54}$ The municipalities are obligated to include these goals in their annual employment plans but the actual targets are ultimately decided by the municipality in consultation with the local Employment Council, and in dialogue with the PES regional office. Although the municipalities ultimately set their own quantitative targets, they are under strong management pressure from the PES regional offices and must justify the targets they set and are held accountable for achieving them. There are no explicit formal sanctions. There is, however, criticism on the part of some municipalities that the PES regional offices are too intrusive in the ongoing "dialogue process" (Mploy, 2011). ${ }^{55}$

National monitoring and assessment of progress toward the agreed goals is carried out primarily by the four PES employment regions. Advisory Employment Councils at the national regional and local levels are also expected to monitor job centre performance. In principle the relationship between the PES regional offices in monitoring job centre performance is dialogue-based rather than hierarchical with the goal of improving local performance. They meet with the job centres at least every quarter and there is also regular statistical monitoring of results through the Danish national databank for employment indicators. The PES regional office would intervene if the job centre's performance was markedly lower than in other comparable job centres or if there were violations of law. In practice PES regional offices play a very strong role and could, if local employment efforts fall markedly below the results of comparable job centres, recommend that the minister contract out the deficient services to the private sector at the expense of the municipality. This "big stick" has not yet been used (Mploy, 2011).

Transparency and publicity of performance results also play an important role in the Danish accountability framework. Both financial incentives and national goals are monitored through a national registry-based IT system that tracks job centre performance against the minister's annual goals, statutory minimum activation requirements, and other parameters. Results can also be easily compared and benchmarked based on clusters of job centres with similar contextual conditions. The results are publicly available on the PES website, giving local political leaders and managers an additional incentive to be concerned about their performance.

Although in principle municipalities have near complete flexibility in the management of active labour market policies, they are in practice constrained in their activities by a complex system of reimbursement incentives for the (re-)financing of their expenditure for state benefits and active measures intended to steer their policies toward national policy goals.

Job centre managers criticised the complexity of the financing system because its implications are difficult to predict for a given course of action and due to the financial incentive focus on processes, in particular the statutory minimum requirements, and the mix of labour market programmes rather than on labour market goals and outcomes. Moreover, the surge in unemployment as a result of the economic crisis dramatically increased the case loads of the job centres making it difficult to serve clients in a timely

${ }^{53}$ The performance agreement with the PES includes not only labour market outcomes but also numerous PES organisational goals and tasks for the coming year.

${ }^{54}$ For example, no more than 58850 continuously unemployed for more than three months; no more than 63826 youth on benefits (in December 2010).

${ }^{55}$ In an extreme case, if a job centre's performance falls considerably below the results of comparable job centres, the PES is authorised by statute to recommend to the minister that the deficient services be outsourced to a third party at the expense of the municipality. 
manner. Some PES central managers see the problem more in the failure of the municipalities to allocate sufficient resources to the labour market area because they often have other priorities. More fundamentally, insofar as the incentive system primarily rewards outputs (service provision and placements in active measures) rather than outcomes, it may give municipalities a perverse incentive to provide low quality services and measures, as activation of any sort is an end in itself (Bredgaard, 2011).

The system of financial incentives in Denmark was reformed as of January 2011. Some financial penalties for failure to conform to the minimum service standards were eliminated, retaining only those for not delivering activation or contact interviews on time. As part of overall budget cuts, state reimbursements for the administrative costs of active measures were reduced as well as the reimbursement rates for benefit expenditures for municipal participants. The latter were also readjusted to give municipalities a greater incentive for work-related measures (wage subsidies and company internships) deemed to increase outflows into regular employment (Mploy, 2011). ${ }^{56}$

\footnotetext{
${ }^{56}$ Thomas Bredgaard at the Centre for Labour Market Research, Aalborg University, provided additional information on these reforms.
} 


\section{REGIONAL AND LOCAL CAPABILITIES}

Decentralisation is not only an issue of accountability but also of capabilities. Regional and local actors must be able to carry out their tasks efficiently and effectively. These include typically, for example, analysis of local needs, development of appropriate strategies, implementation of programmes, monitoring, controlling and evaluating performance. Design of decentralisation has to take into account the personnel, organisational and fiscal capabilities of regional and local authorities. This includes, if need be, incorporating capacity building in decentralisation policies.

In both Canada (Alberta and New Brunswick) and Belgium (Flanders) the responsibility for active policies is managed and implemented in a largely autonomous fashion by competent and experienced regional PES organisations. Both have exercised this function for many years and whatever start-up problems there may have been are no longer apparent. Moreover, given the population of both (ca. 3.7 million in Alberta and ca. 6.2 million in Flanders) scale is not a problem. Given the sheer size and diversity of Canada in particular, devolution to the provinces and territories appears on the whole to be an appropriate institutional design. The management style of the Alberta and New Brunswick PES, which seems to successfully combine an orientation toward provincial goals with internal flexibility based on short-chains of command, intensive communication and bottom-up planning input, would not be possible in a larger Canada-wide organisation.

A novel feature of the Canadian case is that devolution was voluntary for the provinces and territories and took place gradually over nearly 14 years. Canadian devolution of active policies was therefore asymmetrical for an extended period because they were based on individual agreements with the provinces and territories, which vary greatly in size, administrative capabilities and political will, under which they assumed responsibility for implementing federal employment services. Such a voluntary and selective approach may be useful for adapting the pace of devolution to varied local capabilities.

In both Canada and Belgium there appears to be little effort to develop national tools that might standardise provision of employment service, systematic and comparable performance data, or exchange of experience on more than an $a d$ hoc basis. Active policies have become primarily a provincial or regional responsibility. In Belgium the European Employment Strategy and its Mutual Learning Programme provide, to a certain extent, an alternative framework for these type of activities. Canada would benefit from examining similar approaches in order to facilitate mutual learning and exchange of best practices between governments, and the development, if necessary, of pan-Canadian labour market goals and priorities.

In the Netherlands and Denmark decentralisation of active policies gives far-reaching flexibility to the municipalities in designing and implementing active labour market policies and overseeing the performance of local job centres. In both cases the reforms are relatively recent and both are still evolving. Although the municipalities play a traditionally strong role in public administration in both unitary states, municipalisation seems to be problematic from the point of view of capabilities and scale where municipalities are small. By contrast, larger municipalities are as a rule fully capable of carrying out their new, more autonomous and strategic role.

In Denmark, where the local authorities play an exceptionally strong role in the provision of government services, the delegation of responsibility for implementation to the municipalities was preceded by a comprehensive reform of the structure of local authorities, designed in particular to eliminate smaller municipalities that were deemed to lack the scale and capacities to carry out their tasks 
efficiently and effectively. The reform reduced the number of municipalities from 271 to 98 . At the same time the responsibilities of the municipalities were extended, making them responsible for almost all public services. Still 98 municipalities are a large number for a relatively small country. Although the seven smallest municipalities with less than 20000 inhabitants were required to enter co-operation agreements with larger neighbours, there are still 91 job centres with an average population of about 60000 persons and about $20 \%$ have less than 30000 .

In the Danish accountability framework, the delegation of greater responsibility to the regions is balanced by the retention of a national client-based IT system that monitors municipal performance and a large number of national tools and process standards that are an instrument of central supervision and standardisation, on the one hand, but are also important resources for the municipalities, on the other.

In the Netherlands, unlike in Denmark, there has been no municipal reform to create more viable administrative units. A large number of municipalities (418, greatly varying in size), are responsible for implementing employment services for social assistance recipients. Many are quite small and would seem to lack the scale and administrative capacities for efficient and effective implementation of these services. Thus while larger municipalities have used the flexibility offered by the decentralised system to develop new approaches, smaller ones have, with few exceptions, continued past policies. This appears to be due in part to lack of staff and competencies needed to develop new approaches as well as to the fact that, given their smaller size, the potential benefits are less. This situation has led some small municipalities to conclude co-operative agreements with others (Van Geuns and van Gent, 2008).

Since 2009 Dutch policy has promoted the establishment of work squares in order to overcome institutional fragmentation in service delivery and address problems of scale. In some cases several municipalities participate in a single work square with the PES. Moreover, in response to the economic crisis 30 work square plus centres were established, mostly in larger cities, for activities for which the local level is not deemed appropriate (e.g. mobility centres for displaced workers and special regional programmes for youth). Although co-operation is required by law, municipal involvement is in practice voluntary and based on local agreement. In January 2010 there were 127 work squares in which the degree of co-operation was very uneven ${ }^{57}$ (Dorenbos and Froy, 2011).

There is, in contrast to Denmark, less central support in the Netherlands for capacity building in the municipalities to support their exercise of new responsibilities. This is to a certain extent a consequence of the greater discretion they enjoy since most classical elements of central performance management are absent. There is a national policy embodied in law but there are, at the national level, no management goals or targets, no common IT system to monitor performance, no service guidelines, or minimum standards for employment services. For the most part these never existed in the traditionally highly decentralised system of local social services and an explicit goal of the social services reform was "de-reporting", i.e. reduction in information burdens. The result of this much more radical substitution of financial incentives for performance management is that the responsible ministry lacks easily available information to exercise its oversight responsibilities. One consequence has been that the central government now resorts frequently to burdensome ad hoc investigations to satisfy its information needs.

Although an instrument of central steering, these accountability instruments are also a management resource for the municipalities in managing and assessing their own performance, which now have to be developed locally in order to carry out their increased responsibilities.

57.The degree of co-operation varied greatly with only about half reporting a high level of co-operation or (in most cases) the intention to do so, whereas $40-50 \%$ had no plans for greater co-operation. 


\section{SUMMARY AND CONCLUSIONS: ACCOUNTABILITY IN MULTI-LEVEL GOVERNANCE}

\section{Decentralisation}

In the past three decades there has been a strong trend toward decentralisation in labour market policies in OECD countries. There have been two principal types of decentralisation: (1) managerial decentralisation in which regional and local PES offices are given increased operative flexibility in implementing national policy objectives and (2) political decentralisation or devolution, which usually entails a more far-reaching delegation of responsibility to the sub-national (regional, state, or municipal) levels of government.

Managerial decentralisation has usually taken the form of performance management or management by objectives. It is the classical managerial strategy for reconciling local flexibility and accountability and the common denominator in PES organisations.

Political decentralisation of employment services takes diverse forms depending on the institutional setting. Frequent in federal systems, it has also often been an element of regionalisation reforms in previously centralised political-administrative systems (e.g. Italy, Spain). Finally, municipalisation is a third type of political decentralisation, especially in the organisation of services for social assistance recipients, which has historically been a municipal responsibility in many countries.

The four decentralised employment service systems examined here, Canada (Alberta and New Brunswick), Belgium (Flanders), the Netherlands and Denmark, all represent cases of political decentralisation of responsibility for active policies. In Canada this took place within a traditional federal system of government, whereas in Belgium it was part of a broader regionalisation process. In both cases the devolution of responsibility for active policies was part of a decentralisation of the state administration in response to separatist tendencies, whatever specific improvements in the delivery of active policies may have been anticipated.

By contrast the Netherlands, and more recently Denmark, are unitary states in which political decentralisation takes the form of municipalisation of responsibility for active measures. There are complex reasons for this choice in both but there is a common thread. In both countries the implementation of social assistance, including employment services, has historically been a municipal responsibility. National governments concerned about looming labour shortages and fiscal costs came to perceive municipal administration of social assistance as giving too little emphasis to activation and control of abuse. In both cases municipalisation combines elements of decentralisation and centralisation. In Denmark responsibility for employment services for the insured unemployed has been transferred from the PES to the municipalities. In the Netherlands the municipal job centres are still responsible for benefits and employment services for those on social assistance but this is now occurring in the context of a new activation regime for this client group. Both reforms can also be regarded as a step toward centralisation since the previously highly decentralised municipal implementation of benefits and services is now subject to a strong national accountability framework designed to bring municipal practice more in line with national policy objectives.

\section{Accountability regimes}

Accountability regimes and accountability problems in implementation depend in good part on the service delivery model and the extent and type of decentralisation. Multi-level governance of employment services, which we find in different forms in all four cases examined in this paper, is a special case. 
There is a very similar principal-agent problem in both management by objectives within national PES organisations and in multi-level governance, in which responsibility for implementation is delegated to lower tiers of state, provincial, regional or municipal government. In both types of decentralisation the agency problem for the principal (central administration) and the agent (operating agency, regional, or municipal government) is similar. The principal delegate's responsibility to the agent and the principal's interests are affected by the agent's choices. The agency relationship is problematic for the principal because the interests of the principal and the agent may diverge and the principal cannot, without costs, monitor the agent's actions and the information available to the agent. In decentralisation within the public sector "moral hazard" rather than adverse selection can be regarded as the core of the accountability problem. The problem for the principal is to get the agent to act in his interest, however defined, in the presence of asymmetric information. The gravity of the accountability problem in this perspective depends on the extent to which the interests of principal and agent diverge, the possibilities and the costs of controlling the agent and the availability of alternatives.

Political decentralisation in multi-level governance in which responsibility is delegated to states, provinces or municipalities, in comparison with administrative decentralisation in MBO type systems is a special case. The parameters of the accountability problem are in general more problematic. In such institutional settings MBO functions typically only as MBO light, if at all. The interests of the principal and the agent in the multi-level system are as a rule much more diverse, the possibilities of control more limited and more costly. There is, moreover, usually a greater variety of organisational forms with a correspondingly lower level of standardisation and comparability in labour market and performance data. Moreover, the leverage of central authorities over politically independent state, provincial or municipal governments is more limited. In short, the principal-agent relationship inherent in MBO is applicable only in a much weakened form in multi-level governance because the underlying power relationship and information and control problem are fundamentally altered in comparison with MBO in a national PES organisation.

Although decentralisation of the management of active policies for both Alberta and New Brunswick in Canada and Flanders in Belgium is near complete, the regional PES organisation in both are paradoxically centralised top-down organisation that grant only limited flexibility to their own subordinate regional and local agencies.

The accountability frameworks in the municipalisation models for employment services in Denmark and for social assistance in the Netherlands are novel because both systems rely primarily on economic incentives to align the actions of the municipal actors responsible for implementation with national goals. Either they have eliminated most elements of central performance management (the Netherlands) or it survives only in a weakened form (Denmark) where performance management is conceived largely as a dialogue process supported by high transparency of results in a national monitoring system.

The Dutch and Danish experience with financial incentives are an alternative form of central steering suggests that, like quantitative targets in more traditional MBO systems, there is a risk of perverse effects, especially when they reward adherence to processes, volume of entrants into measures or expenditure for benefit payments. In the Danish case there is still a parallel 'dialogue-base' management and national IT system that can identify systemic problems.

By contrast, in the Netherlands performance management of the municipally based system appears to rely almost exclusively on one central financial incentive: expenditure for income benefits. The municipalities are allocated a fixed sum based on a statistical projection. If their payments exceed this amount, they must, in principle, draw on their own funds. Conversely, if expenditure is lower, they can use the funds for other municipal purposes. In contrast to Denmark, there is little regular supervision or even systematic data available on municipal performance. 


\section{Local capabilities}

Decentralisation raises issues not only of central accountability but also of local capabilities. Regional and local actors must be able to carry out their tasks efficiently and effectively. Design of decentralisation has to take into account the personnel, organisational and fiscal capabilities of regional and local authorities. This includes, if necessary, incorporating capacity building measures in decentralisation policies.

In both Canada (Alberta and New Brunswick) and Belgium (Flanders) the responsibility for active policies is managed and implemented in a largely autonomous fashion by competent and experienced regional PES organisations. In the Netherlands and Denmark decentralisation of active policies gives farreaching responsibility to municipalities that vary greatly in size and capabilities.

In Denmark, where the local authorities play an exceptionally strong role in the provision of government services, public policy has addressed the issue of local capacities. Municipalisation of responsibility for employment services was preceded by a local government reform that reduced the number of municipalities from 271 to 98. Moreover, in the Danish accountability framework, the delegation of greater responsibility to the municipalities is balanced by the retention of a national IT system and a large number of other national tools and process standards. Although an instrument of central steering, these accountability instruments are also a management resource for the municipalities in carrying out their new responsibilities.

In the Netherland, unlike in Denmark, there has been no municipal reform; many of the 418 municipalities are quite small. While larger municipalities have used the new flexibility to develop innovative approaches, smaller ones have, with few exceptions, continued past policies. Recent efforts to promote voluntary co-operation between municipalities and the PES in work squares have thus far only been successful in some localities. There is, moreover, little central support in the Netherlands since, unlike in Denmark, all elements of central performance management are absent.

A novel feature of the Canadian case is that devolution was voluntary for the provinces and territories and was implemented with individual agreements that were concluded individually over nearly 14 years. Such a voluntary and selective approach may be a useful model for adapting the pace of devolution to varied local capabilities. 


\section{BIBLIOGRAPHY}

Behrenz, L., L. Delander and H. Niklasson (2001), "Towards intensified local level cooperation in the design and implementation of labour market policies: an evaluation of some Swedish experiments and reforms", Labour Market Policy and Unemployment: Impact and Process Evaluations in Selected European Countries, pp.256-290, Edward Elgar, Aldershot.

Bogaerts, K., et al. (2011), "Building Flexibility and Accountability into Local Employment Services: Country Report for Belgium", OECD Local Economic and Employment Development (LEED) Working Papers, No. 2011/11, OECD Publishing.

Bredgaard, T. (2011), "When the Government Governs: Closing Compliance Gaps in Danish Employment Policies", International Journal of Public Administration 34 (12), pp. 764 777.

Bredgaard, T. and F. Larsen (2009), "Redesigning the Governance of Employment Policiesdecentralised centralization in municipal Jobcenters", The New Governance and Implementation of Labour Market Policies, pp. 45-68, DJOF-Publishers, Copenhagen.

Davies, A. (2001), Accountability. A Public Law Analysis of Government by Contract, Oxford University Press, New York.

De Vries, M. (2000), "The rise and fall of decentralisation: A comparative analysis of arguments and practices in European countries", European Journal of Political Research 38 (2), pp. 193224.

Dorenbos, R. and F. Froy (2011), "Building Flexibility and Accountability into Local Employment Services: Country Report for the Netherlands", OECD Local Economic and Employment Development (LEED) Working Papers, No. 2011/13, OECD Publishing.

Dorrer, J. (2003), "The US: Managing Different Levels of Accountability", Managing Decentralisation. A New Role for Labour Market Policy, OECD Publishing, Paris

Fisman, R. and Roberta Gatti (2002), "Decentralization and corruption: evidence across countries", Journal of Public Economics, Elsevier, vol. 83(3), pp. 325-345.

Froy, F., et al. (2011), "Building Flexibility and Accountability into Local Employment Services: Synthesis of OECD Studies in Belgium, Canada, Denmark and the Netherlands", OECD Local Economic and Employment Development (LEED) Working Papers, No. 2011/10, OECD Publishing.

Giguère, S. and F. Froy (2010), Breaking Out of Policy Silos: Doing More with Less, OECD Publishing, Paris.

Giguère, S. and F. Froy (2009), Flexible Policy and More and Better Jobs, OECD Publishing, Paris.

Harrow, J. (2001), "Capacity Building as a Public Management Goal”, Public Management Review 3:2, pp. 209-230.

De Koning, J. (2009), "Reforms in Dutch Active Labour Policy during the last 20 Years: An Evaluation", SEOR Working Paper No. 2009/2, Rotterdam. 
Larsen, F. (forthcoming), "Active labor market reform in Denmark: The role of governance in policy change", Work and the Welfare State: the Politics and Management of Policy Change, Georgetown University Press, Washington D.C.

Leibfritz, W. (2009), "Fiscal Federalism in Belgium: Main Challenges and Considerations for Reform", OECD Economics Department Working Paper, No. 743, OECD Publishing

Lundin, M. and P. Skedinger (2006), "Decentralisation of active labour market policy: The case of Swedish Local Employment Service Committees”, Journal of Public Economics 90, pp. 775-798.

Mploy (2011), "Building Flexibility and Accountability into Local Employment Services: Country Report for Denmark", OECD Local Economic and Employment Development (LEED) Working Papers, No. 2011/12, OECD Publishing.

Mosley, H., H. Schütz and N. Breyer (2001), "Management by Objectives in European Public Employment Services”, Discussion Paper FSI01-203, Social Science Research Centre, Berlin.

Mosley, H. (2003), "Flexibility and Accountability in Labour Market Policy: A Synthesis", Managing Decentralisation. A New Role for Labour Market Policy, OECD Publishing, Paris.

Mosley, H. and E. Sol (2005) "Contractualism in Employment Services: A Socio-Economic Perspective", Contractualism in Employment Services: A New Form of Welfare State Governance, The Hague: Kluwer Law International, pp. 1-20.

Mosley, H. and P. Bouché (2008), "Local Labour Market Policy in Germany: Decentralisation and Capacity Building at the Regional Level", Competitive Skills: Workforce Development in a Globalised Economy, OECD Publishing, Paris.

Mosley, H. (2009), "The Trade-off between Flexibility and Accountability in Labour Market Policy", Flexible Policy and More and Better Jobs, OECD Publishing, Paris.

Mosley, H. (2010) "Flexibility and Accountability in the Municipalization Reforms in German Employment Services", Paper prepared for RESQ research conference, June 24th \& 25th, Copenhagen.

SZW Ministry of Social Affairs and Employment (2008), "The Work and Social Assistance Act (WWB) in a Nutshell”, SZW, Den Hague.

OECD (1999), Decentralising Employment Policy: New Trends and Challenges, OECD Publishing, Paris.

OECD (2003), Managing Decentralisation. A New Role for Labour Market Policy, OECD Publishing, Paris.

Richards, S. (1994), "Devolving Public Management, Centralizing Public Policy", Oxford Review of Economic Policy, 10 (3), pp. 40-50.

Ruiz, D. (2003), “Spain: Modernisation through Regionalisation”, Managing Decentralisation. A New Role for Labour Market Policy, OECD Publishing, Paris.

Rymes, D. (2003), "Partnerships across Levels", Managing Decentralisation. A New Role for Labour Market Policy, OECD Publishing, Paris. 
Sell, S. (2008), "Die schiefe Ebene der Standardisierung und Zentralisierung”, Experise für die LAG Arbeit Hessen, Remagener Beiträge zur aktuellen Sozialpolitik.

Sol, E. and M. Westerfeld (eds.) (2005), Contractualism in Employment Services, Amsterdam University Press, Amsterdam.

Straits, R. (2003), “The US: Decentralisation from the Bottom Up”, Managing Decentralisation. A New Role for Labour Market Policy, OECD Publishing, Paris.

Struyven, L. and K. Verhoest (2005), "The Problem of Agency at Organizational Level and Street Level: The Case of the Flemish Public Employment Service", Employment Services. A New Form of Welfare State Governance, The Hague: Kluwer Law International, pp. 325-357.

Struyven, L. and L. van Hemel (2009), "The Local Integration of Employment Services: Assessing network effectiveness of local job centers in Flanders", Environment and Planning $C$ : Government and Policy 27 (6) pp. 1055-1071.

Struyven, L. (2010), "Soft Characteristics as Barriers to Activation and Employment", Paper prepared for the RESQ research conference, June 24th \& 25th, Copenhagen.

Tiebout, C. (1956), “A pure theory of local expenditure”, Journal of Political Economy 64, pp. 416 424.

Van Berkel, R. (2009), "Bureaucracies under Pressure? How Dutch Local Welfare Agencies Cope with Policy and Governance Reforms", The New Governance and Implementation of Labour Market Policies, pp. 115-38, DJOF Publishers, Copenhagen.

Van Geuns, R. and M. van Gent (2008), "The Work and Social Assistance Act (WWB) in the Netherlands: An Independent Perspective", Regioplan, Amsterdam.

Wood, D. (2010), "Building Flexibility and Accountability into Local Employment Services: Country Report for Canada", OECD Local Economic and Employment Development (LEED) Working Papers, No. 2010/17, OECD Publishing, Paris. 